\title{
KANDUNGAN UNSUR HARA PADA PUPUK ORGANIK \\ TUMBUHAN AIR LOKAL
}

The nutrient content of organic fertilizers on local aquatic plants

\author{
Pienyani Rosawanti \\ Dosen Program Studi Agroteknologi Fakultas Pertanian dan Kehutanan \\ Universitas Muhammadiyah Palangkaraya \\ Email: pienyani@yahoo.com
}

\begin{abstract}
Abstrak
Eceng gondok, kiambang dan kayu apu merupakan tumbuhan air yang banyak terdapat Kalimantan Tengah yang dapat dimanfaatkan sebagai pupuk organik. Penelitian ini bertujuan untuk mengetahui kandungan unsur hara pada pupuk organik padat dan cair pada pupuk eceng gondok, kiambang dan kayu apu.

Hasil penelitian menunjukkan bahwa pupuk organik padat/kompos dan pupuk cair eceng gondok, kayu apu dan kiambang memilki kandungan unsur hara yang diperlukan oleh tanaman. Pada pupuk padat/kompos, kandungan Nitrogen Kiambang sebesar $2.43 \%$ dan masuk dalam standar minimal persyaratan pupuk organik padat, sedangkan kandungan Phospor dan Kalium tidak masuk dalam standar. Pada pupuk organik cair, kandungan Nitrogen, Phospor dan Kalium tidak masuk dalam standar minimal persyaratan pupuk organik cair
\end{abstract}

Kata kunci : eceng gondok, kayu apu, kiambang, pupuk organik, unsur hara

\begin{abstract}
Water hyacinth, giant salvinia and water lettuce are widely available in Central Kalimantan that can be used as organic fertilizer. This study aims to determine the nutrient content of solid and liquid organic fertilizers in water hyacinth, giant salvinia and water lettuce fertilizers. The results showed that solid organic fertilizer/compost and water hyacinth, water lettuce and giant salvinia liquid fertilizer have nutrient content needed by plants. In solid fertilizers, the Nitrogen of giant salviniacontent was $2.43 \%$ and lack of the minimum standard of solid organic fertilizer, while Phospor and Potassium content were not included in the standard. In liquid organic fertilizer, Nitrogen, Phospor and Potassium content were not included in the minimum standard organic fertilizer requirements
\end{abstract}

Keywords : water hyacinth, giant salvinia, water lettuce, nutrient, and organic fertilizer,

PENDAHULUAN

Provinsi Kalimantan Tengah memiliki perairan umum dengan luasan \pm 2.333.077 Ha dimana 2.267.800 $\mathrm{Ha}$ merupakan daerah perairan tawar. Khusus untuk wilayah Palangka Raya, seluas 2.290.000 Ha, terdiri dari 11 sungai besar, 690 danau dan rawa (Pemprov Kalteng, 2017). Luas perairan air tawar yang cukup besar ini sangat berpotensi untuk perkembangan tanaman air tawar seperti 
kayu apu, kiambang dan enceng gondok. Tumbuhan air merupakan bagian penting dari ekosistem perairan yang dimanfaatkan sebagai agen fitoremediasi, perangkap bahan organik di perairan eutrofik serta membersihkan dan mengontrol pencemaran logam berat, pestisida dan minyak (Tuti dan Indriatmoko, 2018). Populasi tanaman air atau sering disebut dengan gulma air sangat bermanfaat bagi ekosistem perairan terutama sebagai fitoremediasi. Fitoremediasi didefinisikan sebagai pencucian polutan yang dimediasi oleh tumbuhan, termasuk pohon, rumputrumputan dan tumbuhan air (Hidayati, 2005). Tetapi jika populasi tumbuhan air tersebut sangat tinggi dapat menyebabkan menurunnya jumlah cahaya yang masuk ke dalam perairan sehingga menyebabkan menurunnya tingkat kelarutan oksigen dalam air. Hal ini dapat membahayakan organisme yang hidup di air seperti ikan. Melimpahnya tanaman air tersebut dapat dimanfaatkan sebagai sumber bahan organik untuk pembuatan pupuk organik sehingga dapat mengurangi kepadatan populasinya di dalam air. Tumbuhan air merupakan salah satu keanekaragaman hayati yang terdapat di sungai atau rawa di Kalimantan Tengah. Keberadaan tumbuhan air seperti pandan, eceng gondok (Eichhornia crassipes), teratai
(Nymphaea), kangkung (Ipomoea aquatica), kiambang (Salvinia molesta) dan kayu apu (Pistia stratiotes L.) di perairan rawa/sungai memiliki keanekaragaman spesies yang tinggi. Tumbuhan air tersebut dikategorikan sebagai gulma air. Tingginya keanekaragaman spesies tersebut disebabkan kondisi perairan yang belum mengalami pencemaran. Tumbuhan air mampu menurunkan bahan pencemar limbah cair, Seng ( $\mathrm{Zn})$, DO (Dissolved Oxygen), Suhu, Derajat Keasaman (pH), BOD (Biological Oxygen Demand), COD (Chemical Oxygen Demand), TSS (Total Suspended Solid), Kekeruhan (Turbidity) dan Amoniak $\left(\mathrm{NH}_{3}\right)$ pada limbah cair industri karet (Nurhidayah et al., 2014).

Pada bidang pertanian, pupuk sangat diperlukan untuk meningkatkan pertumbuhan dan produksi tanaman. Penggunaan pupuk kimia yang berlebihan dapat berdampak negatif pada tanah dan lingkungan. Dampak negatif tersebut harus dihentikan atau setidaknya dikurangi. Salah satu cara untuk mengurangi penggunaan pupuk kimia adalah penggunaan pupuk organik. Formula pupuk organik adalah komposisi bahanbahan organik dan mineral penyusun pupuk organik (Permentan NOMOR 70/Permentan/SR.140/10/2011). Sumber 
bahan organik dapat berupa kompos, pupuk hijau/tanaman, pupuk kandang, sisa panen (jerami, brangkasan, tongkol jagung dan sabut kelapa), limbah ternak, limbah industri yang menggunakan bahan pertanian dan limbah kota (Roidah, 2013). Berdasarkan bentuknya, pupuk organik dibedakan menjadi dua, yaitu: pupuk cair dan pupuk padat (Hadisuwito, 2012).

Kayu apu, kiambang dan eceng gondok merupakan tumbuhan air yang tumbuh mengapung dan dikategorikan sebagai gulma air atau tumbuhan mengganggu bila pertumbuhan dan penyebarannya sangat tinggi. Tumbuhan air tesebut dapat dimanfaatkan sebagai bahan organik untuk pupuk organik (Nugroho, 2010). Menurut Moi et al. (2015) pemberian pupuk organik eceng gondok dapat meningkatkan produksi tanaman sawi. Penambahan kayu apu dapat mengurangi penggunaan pupuk anorganik pada tanaman padi sawah (Putri et al., 2013). Pada penelitian Gusta et al. (2015) kiambang digunakan sebagai media campuran tanah topsoil dan sabut kelapa merupakan komposisi media tanam terbaik pada bibit kelapa sawit pre nursery.

Melimpahnya tanaman air yang ada di Kalimantan Tengah menjadi dasar untuk mengembangkan pemanfaatan tanaman air lokal di Kalimantan Tengah sebagai pupuk organik untuk nutrisi tanaman budidaya. Tujuan dari penelitian ini adalah: mengetahui kandungan unsur hara pada pupuk organik tumbuhan air lokal Kalimantan Tengah.

\section{METODOLOGI}

Penelitian pembuatan pupuk dilakukan di Kebun Mini, Fakultas Pertanian dan Kehutanan, Universitas Muhammadiyah Palangkaraya Kalimantan Tengah sedangkan analisis kandungan unsur hara dilakukan di Laboratorium MIPA Fakultas MIPA Universitas Palangka Raya. Bahan yang digunakan pada penelitian ini adalah tanaman air (kayu apu, kiambang dan eceng gondok), limbah nanas termasuk kulit, air cucian beras, gula pasir sedangkan bahan yang digunakan adalah pisau, telenan, terpal, ember, gembor, $\mathrm{pH}$ meter, timbangan, tong, karung, alat tulis menulis dan alat dokumentasi.

\section{Pembuatan Mol Kulit Nanas}

Langkah-langkah pembuatan: limbah kulit nanas dipotong-potong, kemudian siapkan air cucian beras dalam ember. Gula pasir dilarutkan kemudian dicampur dengan air cucian beras, lalu masukkan limbah/kulit nanas ke dalam larutan air cucian beras dan aduk hingga merata, tutup ember dan diamkan selama 2 minggu. Setiap 3 hari 
dibuka tutupnya untuk membuang gas. Setelah 2 minggu mol siap digunakan dengan ciri aroma seperti tape.

\section{Pembuatan Pupuk Organik Padat/Kompos}

Bahan-bahan pembuatan pupuk organik padat/kompos adalah: eceng gondok, kayu apu dan kiambang masing-masing sebanyak 4 kg. Langkah-langkah pembuatan pupuk organik padat/kompos adalah sebagai berikut: eceng gondok, kayu apu dan kiambang dipotong-potong dengan ukuran $2 \mathrm{~cm}$ kemudian dikeringanginkan. Tanaman air yang telah dipotong kemudian dimasukkan ke dalam karung secara terpisah tergantung jenis tanamannya. Kemudian tambahkan larutan mol kulit nanas yang telah difermentasi. Mol diencerkan dengan air dengan perbandingan 1:5. Laruan mol diberikan sampai kandungan air bahan sebesar 30\%. Bila adonan dikepal dengan tangan, air tidak keluar dari adonan, dan bila kepalan dilepas adonan akan mekar. Penambahan mol nanas dilakukan secara perlahan sambil diaduk agar seluruh tanaman air tercampur rata dengan larutan mol kulit nanas. Setelah itu tanaman yang sudah tercampur merata dengan mol diinkubasi selama 4 minggu. Karung yang berisi bahan kompos disimpan dalam wadah yang tertutup. Setelah kompos matang dengan ciri-ciri berwarna coklat kehitam-hitaman dan tidak berbau dilakukan analisis kandungan unsur hara.

\section{Pembuatan Pupuk Organik Cair}

Bahan-bahan pembuatan pupuk organik cair adalah: eceng gondok, kayu apu dan kiambang masing-masing sebanyak $4 \mathrm{~kg}$. Langkah-langkah pembuatan pupuk organik cair adalah sebagai berikut: eceng gondok, kayu apu dan kiambang dipotongpotong dengan ukuran $2 \mathrm{~cm}$ kemudian dikering anginkan. Tanaman air yang telah dipotong kemudian dimasukkan ke dalam ember secara terpisah tergantung jenis tanamannya. Tambahkan larutan mol kulit nanas yang telah difermentasi dengan dosis 1 liter dan dicampur dengan 5 liter air, kemudian ember ditutup dan difermentasi selama 4 minggu. Simpan di tempat yang teduh selama 4 minggu. Pupuk cair yang sudah jadi dengan ciri-ciri berbau harum seperti tape, disaring dan dimasukkan ke dalam botol. Kemudian pupuk cair tersebut dipersiapkan untuk diuji kandungan unsur haranya.

\section{Analisis Kandungan Unsur Hara}

Analisis kandungan unsur yang terdapat di dalam pupuk organik baik kandungan unsur hara pupuk organik cair dan padat meliputi $\mathrm{pH}$ dan unsur-unsur hara dilakukan di Laboratorium MIPA 
Fakultas MIPA Universitas Palangka Raya.
Hasil analisis kandungan unsur hara pupuk organik dari tumbuhan air dapat dilihat pada Tabel 1 dan Tabel 2.

\section{HASIL DAN PEMBAHASAN}

Tabel 1. Hasil analisis kandungan hara pupuk kompos

\begin{tabular}{ccccc}
\hline Bahan Pupuk & pH H2O & $\begin{array}{c}\text { N-Total } \\
(\%)\end{array}$ & $\begin{array}{c}\text { P Total } \\
(\mathrm{ppm})\end{array}$ & $\begin{array}{c}\text { K-Total } \\
(\mathrm{ppm})\end{array}$ \\
\hline Eceng Gondok & 7.97 & 0.67 & 2208.87 & 9409.33 \\
\hline Kayu Apu & 6.27 & 1.82 & 1317.64 & 16857.04 \\
\hline Kiambang & 7.08 & 2.43 & 1239.68 & 8145.18
\end{tabular}

Ket: $\quad$ Hasil Analisis Laboratorium MIPA Fakultas MIPA Universitas Palangka Raya (2019).

Tabel 2. Hasil analisis kandungan hara pupuk cair

\begin{tabular}{ccccc}
\hline Bahan Pupuk & $\mathrm{pH} \mathrm{H} 2 \mathrm{O}$ & $\begin{array}{c}\text { N-Total } \\
(\mathrm{ml} / \mathrm{l})\end{array}$ & P Total $(\mathrm{ml} / \mathrm{l})$ & $\begin{array}{c}\text { K-Total } \\
(\mathrm{ml} / \mathrm{l})\end{array}$ \\
\hline Eceng Gondok & 4.61 & 1.04 & 5.36 & 37.56 \\
\hline Kayu Apu & 4.39 & 0.70 & 6.25 & 33.86 \\
\hline Kiambang & 3.44 & 0.89 & 6.58 & 60.52
\end{tabular}

Ket: Hasil Analisis Laboratorium MIPA Fakultas MIPA Universitas Palangka Raya (2019).

Berdasarkan hasil analisis Laboratorium (Tabel 1 dan 2) menunjukkan bahwa pupuk organik baik pupuk organik cair maupun pupuk organik padat/kompos mempunyai kandungan unsur hara makro dengan jumlah yang beragam. Gusmini et al. (2008), menyatakan bahwa pemberian bahan organik dapat meningkatkan kandungan hara $\mathrm{N}, \mathrm{P}$ dan $\mathrm{K}$ dalam tanah dan dapat meningkatkan kesuburan tanah dengan cara memperbaiki sifat fisik, kimia dan biologi tanah (Rosmarkam dan Yuwono, 2001). Secara fisik bahan organik dapat memperbaiki struktur tanah, meningkatkan daya menahan air, secara kimia bahan organik meningkatkan kapasitas pertukaran kation (KTK) sehingga kemampuan mengikat kation tinggi.dan secara biologi, bahan organik memperbaiki kehidupan biologi tanah.

Nitrogen berfungsi sebagai penyusun klorofil (bahan kimia hijau yang memungkinkan tanaman untuk menangkap energi dari matahari untuk proses disebut fotosintesis) dan asam amino (protein) memperkuat pertumbuhan, mendukung percabangan/anakan, produksi daun, 
pembesaran ukuran dan pembentukan hasil tanaman (Hardjowigeno, 1987; Rosmarkam dan Yuwono, 2002; Roy et al., 2006).

Phospor merupakan bagian dari beberapa senyawa termasuk minyak dan asam amino. Senyawa $\mathrm{P}$ adenosine difosfat (ADP) dan adenosin trifosfat (ATP) bertindak sebagai pembawa energi di dalam tanaman. Phospor berfungsi untuk pembelahan sel, pembentukan albumin, pembentukan bunga, buah, dan biji (Roy et al., 2006). Selain itu, fosfor juga berfungsi untuk mempercepat pematangan buah, memperkuat batang, untuk perkembangan akar, memperbaiki kualitas tanaman, metabolisme karbohidrat, membentuk nukleoprotein (sebagai penyusun RNA dan DNA) dan menyimpan serta memindahkan energi seperti ATP. Unsur fosfor juga berfungsi untuk meningkatkan ketahanan terhadap penyakit (Hardjowigeno, 1987).

Kalium adalah nutrisi mineral paling banyak kedua dalam tanaman setelah N. K berfunsi sebagai agai aktivator enzim (sekitar 80 jenis enzim yang aktivasinya memerlukan unsur $\mathrm{K}$ ), membantu penyerapan air dan unsur hara dari tanah oleh tanaman, membantu transportasi hasil asimilasi dari daun ke jaringan tanaman. Selain itu K berperan dalam pembentukan pati, mengaktifkan enzim, pembukaan stomata (mengatur pernapasan dan penguapan), proses fisiologis dalam tanaman, proses metabolik dalam sel, mempengaruhi penyerapan unsur-unsur lain, mempertinggi daya tahan terhadap kekeringan, penyakit selain itu juga berperan dalam perkembangan akar. Kegunaan unsur hara $\mathrm{K}$ bagi tanaman yang lain adalah mengaktifkan kerja beberapa enzim asetik thiokinase, aldolase, pirivat kinase, glutamilsistein sinterase, formil tetrahidrofolatsintetase, suksinil CoA sintetase, induksi nitrat reduktase, sintesis tepung, ATP ase. Kalium juga memacu translokasi karbohidrat dari daun ke organ tanaman yang lain, terutama organ tanaman penyimpan karbohidrat, misalnya ubi. Kalium juga merupakan komponen penting di dalam mekanisme pengaturan osmotik di dalam sel dan juga berpengaruh langsung terhadap tingkat semipermiabilitas membran dan fosforilasi di dalam khloroplast (Hardjowigeno, 1987; Rosmarkam dan Yuwono, 2002; Roy et al., 2006).

Kandungan kompos yang berasal dari eceng gondok adalah Nitrogen sebesar $0.67 \%$, Phospor sebesar $0.22 \%$ dan Kalium sebesar $0.940 \%$. Kandungan kompos yang berasal dari kayu apu adalah Nitrogen sebesar $1.82 \%$, Phospor sebesar $0.13 \%$ dan Kalium sebesar $0.16 \%$ Kandungan 
kompos yang berasal dari kiambang adalah Nitrogen sebesar $2.43 \%$, Phospor sebesar $0.12 \%$ dan Kalium sebesar $0.81 \%$.

Kandungan unsur Nitrogen tertinggi pada pupuk kompos kiambang dibandingkan dengan pupuk kompos eceng gondok dan kayu apu. Kandungan unsur hara Nitrogen pada pupuk kompos kiambang masuk dalam standart minimal pupuk organik padat menurut Keputusan Menteri Pertanian Republik Indonesia No. 261/KPTS/SR.310/M/4/2019 Tentang Persyaratan Minimal Pupuk Organik, Pupuk Hayati dan Pembenah Tanah sedangkan pupuk kompos eceng gondok dan kayu apu tidak masuk standar. Kandungan unsur Phospor dan Kalium pada ketiga pupuk kompos sangat rendah dan tidak masuk dalam standar minimal pupuk padat. Standar minimal kandungan Nitrogen, Phospor dan Kalium pada pupuk organik padat/kompos menurut Keputusan Menteri Pertanian Republik Indonesia No. 261/KPTS/SR.310/M/4/2019 minimal 2\%.

. Kandungan pupuk cair yang berasal dari eceng gondok adalah Nitrogen sebesar $1.04 \mathrm{mg} / \mathrm{l}$, Phospor sebesar $5.36 \mathrm{mg} / \mathrm{l}$, Kalium sebesar 37.56 mg/l, kandungan pupuk cair yang berasal dari kayu apu adalah Nitrogen sebesar $0.70 \quad \mathrm{mg} / \mathrm{l}$, Phospor sebesar $6.25 \mathrm{mg} / \mathrm{l}$, Kalium sebesar $33.86 \mathrm{mg} / \mathrm{l}$. Kandungan pupuk cair yang berasal dari kiambang adalah Nitrogen sebesar $0.89 \mathrm{mg} / \mathrm{l}$, Phospor sebesar 6.58 mg/l, Kalium sebesar 60.52 mg/l.

Kandungan unsur Nitrogen, Phospor dan Kalium pada ketiga pupuk organik cair sangat rendah dan tidak masuk dalam standar minimal pupuk organik cair. Standar minimal kandungan Nitrogen, Phospor dan Kalium pada pupuk organik cair menurut Keputusan Menteri Pertanian Republik Indonesia No. 261/KPTS/SR.310/M/4/2019 minimal 2\%.

\section{SIMPULAN DAN SARAN}

\section{Simpulan}

Pupuk organik kompos dan pupuk cair eceng gondok, kayu apu dan kiambang memilki kandungan unsur hara yang diperlukan oleh tanaman. Kandungan kompos yang berasal dari eceng gondok yaitu Nitrogen $0.67 \%$, Phospor $0.22 \%$ dan Kalium $0.940 \%$, kayu apu yaitu Nitrogen $1.82 \%$, Phospor $0.13 \%$ dan Kalium $0.16 \%$, kiambang yaitu Nitrogen $2.43 \%$, Phospor $0.12 \%$ dan Kalium 0.81\%. Kandungan unsur hara Nitrogen pada pupuk kompos kiambang masuk dalam standart minimal pupuk organik padat menurut Keputusan Menteri Pertanian Republik Indonesia No. 261/KPTS/SR.310/M/4/2019. Standart minimal kandungan Nitrogen, Phospor dan Kalium pada pupuk organik padat/kompos 
menurut Keputusan Menteri Pertanian Republik Indonesia No. 261/KPTS/SR.310/M/4/2019 minimal 2\%.

Kandungan pupuk cair yang berasal dari eceng gondok yaitu Nitrogen 1.04 mg/l, Phospor 5.36 mg/l dan Kalium 37.56 $\mathrm{mg} / \mathrm{l}$, kayu apu yaitu Nitrogen $0.70 \mathrm{mg} / \mathrm{l}$, Phospor 6.25 mg/l dan Kalium 33.86 mg/l, kiambang yaitu Nitrogen $0.89 \mathrm{mg} / \mathrm{l}$, Phospor $6.58 \mathrm{mg} / \mathrm{l}$ dan Kalium $60.52 \mathrm{mg} / \mathrm{l}$. Kandungan unsur Nitrogen, Phospor dan Kalium pada ketiga pupuk organik cair sangat rendah dan tidak masuk dalam standarminimal pupuk organik cair. Standar minimal kandungan Nitrogen, Phospor dan Kalium pada pupuk organik cair menurut Keputusan Menteri Pertanian Republik Indonesia No. 261/KPTS/SR.310/M/4/2019 minimal 2\%.

\section{Saran}

Penggunaan dan pembuatan pupuk organik padat kompos dan pupuk organik cair perlu ditambahkan bahan yang mempunyai kandungan nitrogen, phosphor dan kalium tinggi.

\section{DAFTAR PUSTAKA}

Astuti LP dan Indriatmoko. 2018. Kemampuan Beberapa Tumbuhan Air dalam Menurunkan Pencemaran
Bahan Organik dan Fosfat untuk Memperbaiki Kualitas Air Jurnal Teknologi Lingkungan: 19(2)

oyd, C. E., 1968. Fresh-water plants: A potential source of protein. Econ. Bot., 22 (4): 359-3

Gusmini, Yulnafatmawita, dan Daulay AF. 2008. Pengaruh Pemberian Beberapa Jenis Bahan Organik terhadap Peningkatan kandungan hara N, P, K Ultisol Kebun Percobaan Faperta Unand Padang. J. Solum 5(2): 57-65

Gusta AR, Kusumastuti A dan Parapasan Y. 2015. Pemanfaatan kompos kiambang dan sabut kelapa sawit sebagai media tanam alternatif pada prenursery kelapa sawit (Elaeis guineensis Jacq.). Jurnal Penelitian Pertanian Terapan (15) 2: 151-155

Hadisuwito, S. 2012. Membuat Pupuk Organik Cair. PT. Agro Media Pustaka: Jakarta Selatan

Hardjowigeno S. 1987. Ilmu Tanah. Mediyatama Sarana Perkasa. 233 hal.

Hidayati N. 2005. Fitoremediasi dan Potensi Tumbuhan Hiperakumulator. Hayati, 12 (1): 35-40

Kementan RI. 2019. Persyaratan Minimal Pupuk Organik, Pupuk Hayati dan Pembenah Tanah. Keputusan Menteri Pertanian Republik 
IndonesiaNo.261/KPTS/SR.310/M/4 12019 .

Moi AR, Pandiangana D, Siahaana P dan Tangapoa AM. 2015. Pengujian pupuk organik cair dari eceng gondok (Eichhornia crassipes) terhadap pertumbuhan tanaman sawi (Brassica juncea). Jurnal MIPA Unsrat Online 4 (1): 15-19

Nugroho P. 2010. Panduan membuat pupuk kompos cair. Pustaka Baru Prss. Yogyakarta. 204 hal

Pemprov Kalteng. 2017. Capaian implementasi 4 fokus area rencana aksi Gerakan Nasional Penyelamatan Sektor Kelautan Indonesia di Provinsi Kalimantan Tengah

Permentan No. 70/Permentan/SR.140/10/2011.

Pupuk Organik, Pupuk Hayati dan Pembenah Tanah

Roidah IS. 2013. Manfaat penggunaan pupuk organik untuk kesuburan. Jurnal Universitas Tulungagung. Bonorowo (1) 1: 30-42

Rosmarkam A dan Yuwono NW. 2002. Ilmu Kesuburan Tanah. Kanisius Yogyakarta. 224 hal

Roy RN, Finck A. Blair GJ,dan Tandon HIS. 2006. Plant nutrition for food security: A guide for integrated nutrient management. Food And Agriculture Organization of The United Nations. Rome. 366 hal 